\title{
Racing against time, an unprecedented year: the US Army Corps of Engineers (USACE) response to the hurricanes of 2004
}

\author{
R. I. McMillen ${ }^{1}$, D. R. Haubner ${ }^{2}$, R. Srinivas $^{3}$ \& J. R. Proni ${ }^{4}$ \\ ${ }^{1}$ Project Management Division, Jacksonville District, USACE, USA \\ ${ }^{2}$ Planning Division, Jacksonville District, USACE, USA \\ ${ }^{3}$ Taylor Engineering, Inc., USA \\ ${ }^{4}$ Atlantic Oceanographic and Meteorological Laboratory, NOAA, USA
}

\begin{abstract}
The hurricane season of 2004 brought significant damage to the southeast United States through wind, wave, and flooding effects. Executing the recovery missions resulted in enormous workloads and many logistical challenges as hurricane after hurricane continued to impact the southeast. The US Army Corps of Engineers were tasked with several key missions to assist victims of the hurricanes in recovery efforts and in preparing for the next hurricane season. One element of this mission, requiring an emergency response to hurricane impacts on Federal Shore Protection Projects totalling nearly 82 miles of coastal shoreline, resulted in the placement of nearly 18 million cubic yards of sand to mitigate for the hurricane impacts and restore the projects to their authorized design levels. Although these projects experienced large erosion losses due to the prolonged storms, they performed as intended and designed. This paper presents the impacts of the 2004 hurricane season on the Federal projects, their performance during the storms, and the resulting emergency restoration efforts. This paper also provides comparisons of hurricane impacts on protected shorelines versus non-protected shorelines; such comparisons highlight the successes of beach nourishment.

Keywords: beach and dune erosion, hurricane impacts, storm damage, coastal management, post-storm recovery, storm response, shore protection project, storm surge, beach nourishment, US Army Corps of Engineers.
\end{abstract}




\section{Introduction}

The citizens of the southeastern United States (US) will long remember the 2004 Hurricane season. A total of 14 named tropical storms, nine hurricanes, and six major hurricanes developed during the season. Occurring between August and September, four of these storms - Hurricanes Charley, Frances, Ivan, and Jeanne - caused most of the intense devastation that affected the southeast US and particularly the State of Florida. Figure 1 shows the tracks of the four storms. The devastating effects of four major storms occurring over such a short duration required the mobilization of agencies such as the Federal Emergency Management Agency (FEMA), the State of Florida's emergency management organizations, the Salvation Army, the Red Cross, the US Army Corps of Engineers (USACE), and many volunteer organizations. The main recovery missions included 1) debris removal, 2) ice and water delivery, 3) temporary housing, 4) flood control, 5) temporary roofing, and 6) emergency power. All of the agencies and organizations worked in cooperation to provide relief to the victims. In addition to meeting the immediate needs of the victims, the USACE performed emergency restoration of Federal Shore Protection Projects (SPP) which, though experiencing large erosion losses, performed as designed.

\section{The Atlantic tropical storm season of 2004}

During September 2004, Florida experienced two 100-year storm surge events as Hurricanes Frances and Jeanne made landfall only three weeks apart and within 2 miles of each other, USACE 2005 [1]. Hurricane Jeanne's landfall marked the first time since 1886 that four hurricanes in one tropical season affected any individual state in the US; in particular, this was the first year that Florida experienced four hurricanes in one season since weather records began in 1851, FDEP Frances/Jeanne [2]. Damages to hurricane/shore protection projects from this combination of storms included substantial erosion and damage from wind, wave, and water action. This damage went well beyond the damage ordinarily expected from an individual storm. The proximity of storms in space and in time, combined with large sizes of most storms, produced a cumulative effect: protective material the first storm moved offshore did not have ample time to return onshore before the arrival of succeeding storms.

\subsection{Hurricane Charley}

At 1700 EDT on August $13^{\text {th }}$ Charley made landfall on the southwest coast of Florida just north of Captiva Island in Lee County. Charley made landfall as a Category 4 hurricane with maximum sustained winds estimated at $145 \mathrm{mph}$ and a storm surge estimated over $10 \mathrm{ft}$, FDEP Charley [3]. Coastal barrier islands of Lee County all sustained erosion from the combined effects of storm surge, wave, and wind action. The southeast side of Charlie's center inflicted severe wind damage along its path. Charlie's unique feature, a small tight radius, allowed it to maintain hurricane force winds as it continued across central 
Florida. At 0200 EDT on August 14, Charley remained at hurricane intensity as it exited the east coast of Florida near Daytona Beach, Florida. Maximum sustained winds exceeded $80 \mathrm{mph}$ with higher gusts. Waves around 8 feet and winds from 28 to 37 knots affected the central Atlantic and north Atlantic Florida coast as Charley moved offshore. According to the Red Cross, Charley destroyed over 10,000 dwellings, damaged another 60,000, and caused major structural damage that left another 16,000 dwellings uninhabitable. Insurance industry reports an estimated $\$ 7.4$ billion in damages, FDEP Charley [3].

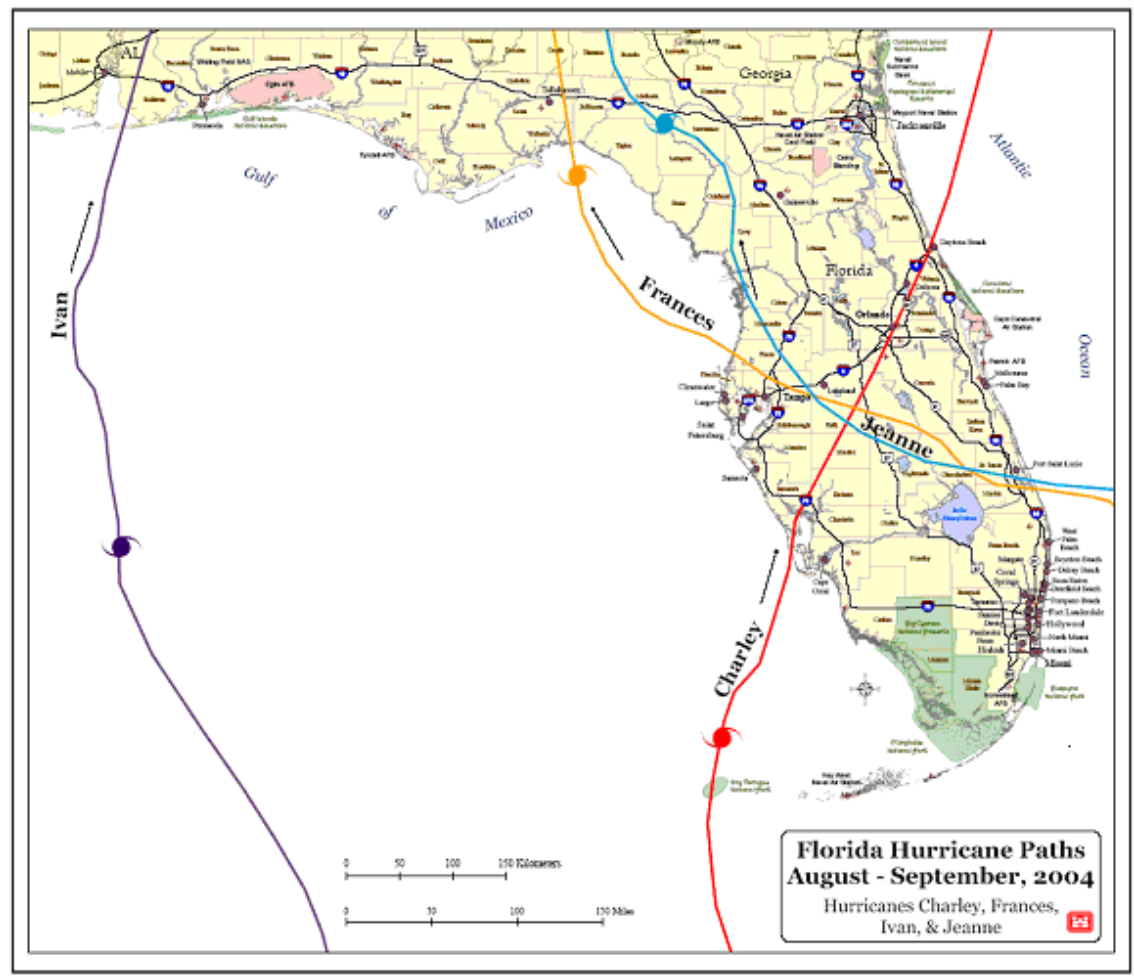

Figure 1: $\quad$ Tracks of Hurricanes Charley, Frances, Ivan, and Jeanne.

\subsection{Hurricane Frances}

At 1700 EDT on September 3, 2004 Hurricane Frances' outer squalls began to reach Florida's east coast as Frances slowed to $6 \mathrm{mph}$ with maximum sustained winds of $105 \mathrm{mph}$. At 0100 EDT on September $5^{\text {th }}$ Hurricane Frances made landfall in northern Martin County on Florida's east coast as a Category 2 storm bringing maximum sustained winds near $105 \mathrm{mph}$ plus higher gusts. Hurricane force winds extended outward 85 miles from the center and tropical storm force winds extended outward 200 miles. High waves also affected much of the coast with 8 to 10 -ft storm surge reported near the landfall location, USACE 2005 [1]. 
Frances, particularly damaging due to its slow pace, impacted much of central and south Florida for up to 30 hours. Six million people lost power at the height of the storm and insured damages across Florida were estimated at 3 to 6 billion dollars, FDEP Frances/Jeanne [3]. Frances became a tropical storm as it continued west-northwest across the Florida peninsula. At 1700 EDT on September $5^{\text {th }}$ the storm's eye was about 20 miles east of Tampa with winds of $70 \mathrm{mph}$. On September $6^{\text {th }}$ the storm exited the state just north of Pinellas County on Florida's west coast and entered the Gulf of Mexico. Frances' large wind and wave fields continued to impact most of the state. The Pinellas County area experienced storm surges of $5 \mathrm{ft}$ along with damaging tropical storm force winds and waves up to $12.5 \mathrm{ft}$, USACE 2005 [1].

\subsection{Hurricane Ivan}

Ivan reached Category 5 strength three separate times as it crossed the Caribbean Sea and entered the Gulf of Mexico. At 0500 EDT on September 15 ${ }^{\text {th }}, 2004$ Hurricane Ivan was a Category 4 hurricane approximately 200 miles southsouthwest of Pensacola, Florida, tracking north-northwest with sustained winds of around $140 \mathrm{mph}$. Hurricane-force winds extended 105 miles from the storm's center, with tropical storm-force winds extending 260 miles. Ivan created a large wave field affecting all of the Panhandle and west coast of Florida. Near 0300 EDT on September $16^{\text {th }}$ Hurricane Ivan made landfall as a Category 3 hurricane with $130 \mathrm{mph}$ maximum sustained winds in Gulf Shores, Alabama. Along the Florida Panhandle beaches, Ivan's storm surge of 10 to 14-ft and extreme wave heights (measured over 50 feet offshore) caused extensive erosion and damage, USACE 2005 [1]. Along the Florida west coast, waves of $10.5 \mathrm{ft}$ were estimated in Pinellas County, USACE 2005 [1]. Reported damages exceeded \$5.5 billion, FDEP Ivan [4].

\subsection{Hurricane Jeanne}

On September $26^{\text {th }}$ Jeanne made landfall on Florida's east coast in northern Martin County. A major Category 3 hurricane at landfall, its maximum sustained winds reached $120 \mathrm{mph}$. Storm surge of 8 to 10 feet was as high as that experienced during Hurricane Frances, FDEP Frances/Jeanne [2]. The landfall location, near Stuart, Florida was very near to where Hurricane Frances made landfall only 20 days earlier. The landfall points were an unprecedented 2 miles apart. As it crossed Florida, Jeanne's track closely resembled Hurricane Frances'. Jeanne was a large hurricane that simultaneously impacted both coasts with damaging waves and winds as it traversed the state. At 1200 EDT on September $26^{\text {th }}$ Jeanne passed east of Tampa and continued moving northnorthwest along Florida's west coast into the Panhandle. Tropical storm force winds extended outward up to 175 miles from the center. A wind gust of $67 \mathrm{mph}$ was reported at St. Petersburg, Pinellas County, and wind speeds ranged from 48 mph in Sarasota on the west coast to $70 \mathrm{mph}$ in St. Augustine on the northeast coast. Wave heights reached $16.5 \mathrm{ft}$ offshore of Pass-A-Grille Beach in Pinellas County, USACE 2005 [1]. An estimated 5-million households were without 
electricity at the height of the storm. Reported damages exceeded $\$ 8$ billion, FDEP Frances/Jeanne [2].

\section{The USACE response}

The Hurricanes of 2004 had serious consequences on the citizens of the southeast United States and the Federal SPP throughout the impacted areas. The USACE was assigned over $\$ 565$ million in FEMA missions related to these storms, Haubner et al. [5]. Over 1,300 personnel engaged in relief efforts placing over 136,000 temporary roofs on damaged structures, delivering 22 million litres of water and over $600,000 \mathrm{lbs}$ of ice to logistical staging areas for distribution, placing 420 emergency generators at hospitals, pump stations and sewage plants, and identifying 57 areas for use as locations for temporary housing, Haubner et al. [5].

\subsection{Emergency beach response}

Due to the sheer magnitude of the storm impacts, coupled with the pending advent of the 2005 hurricane season, the USACE found itself in a race against time. It quickly became apparent that restoration of the SPP was both an urgent and a significant undertaking. The US Congress responded on October 13 with emergency funding for the USACE. Public Law 108-324 appropriated \$210.6 million in funding for the repair of the Federal SPP damaged by the storms, Haubner et al. [5]. Prior to 2004, funding of this magnitude for beach restoration was rare; an annual average of $\$ 15$ million had been appropriated in the past, Haubner et al. [5]. Regional project delivery teams were assembled by October 19. The first major task for the teams was to determine the scope of the recovery efforts. The second task was developing a physical restoration strategy. The toughest challenge facing the USACE in restoring the impacted SPP was overcoming the cumbersome government process that typically takes 3 to 5 years before nourishment commences. This process requires the preparation of Project Information Reports, coordination and consultation with environmental resource agencies to obtain necessary permits and approvals, preparation of plans and specifications, the advertisement and award of contracts, and finally actual construction. Given the short time available before the advent of the 2005 hurricane season, the USACE did not have the luxury of taking 3 to 5 years to deliver projects. Compounding the matter were several factors unrelated to the USACE process. Probably the most important factor was the availability of dredging equipment. Although it was critical that the beaches be restored, it was just as important to maintain the navigation ability of waterways across the nation. So, competition for dredging equipment was intense. Another factor that weighed heavily in the restoration strategy was turtle nesting season. Several of the SPP had to be completed by April 30 to avoid impacting nesting turtles. Ongoing FEMA missions were another factor. Those missions were pulling enormous manpower resources from within the USACE, resources that could easily delay the beach restoration efforts. 


\subsection{Scope of beach restoration}

The first major task in the emergency beach response was to determine the scope of the restoration efforts. The USACE teams, once established, were required to evaluate the storm impacts on 30 Federal SPP to determine eligibility for emergency restoration. Each project had to meet three criteria in order to qualify for restoration. First, the project must have been previously constructed. Second, at least a third of previously placed material must have been lost due to the storms. Last, the non-Federal sponsors must have requested in writing their desire for emergency restoration; some did not.
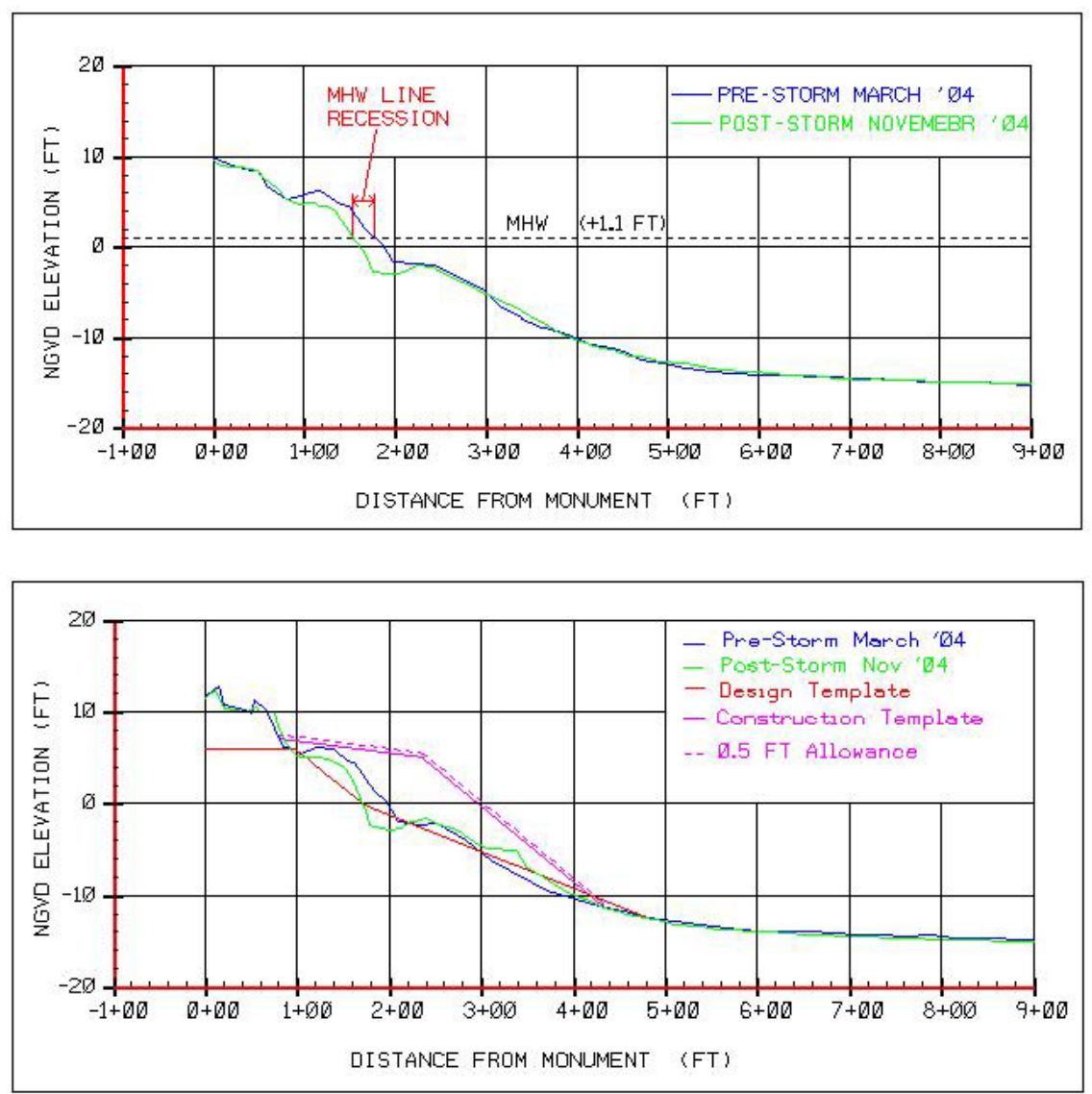

Figure 2: A typical comparison of storm surveys, MHW recession, and design and construction templates.

In general, the 2004 hurricanes resulted in a large amount of beach erosion, with shoreline recession extending landward into the dune line along several reaches of the individual SPP. Storms narrowed and deflated the wide pre-storm 
berm. In order to determine beach volume and shoreline changes for each project caused by the passage of the hurricanes, pre- and post-storm surveys from March 2004 and November 2004, respectively, were compared. Both surveys covered the full length of the Federal project area and extended about 3,000 feet seaward. The surveys were used to compute mean high water (MHW) shoreline and beach volume changes. Averaging the shoreline results provided overall shoreline change estimates and applying the average end-area method provided total beach volume changes for each project. In addition to volume changes between preand post-storm conditions, volume differences between post-storm conditions and the authorized project design berm template as well as changes between post-storm conditions and the project construction template were also determined. The purpose of this analysis is to determine the storm impacts on the project design berm and the necessary volume of fill required to restore the authorized design or the construction template along the entire length of the project. Though the authorized design profile for each Federal SPP varies, it generally consists of a berm with a defined elevation, width, and an equilibrated face slope. Figure 2 illustrates a typical profile including pre- and post-storm surveys, MHW recession, and design and construction templates.

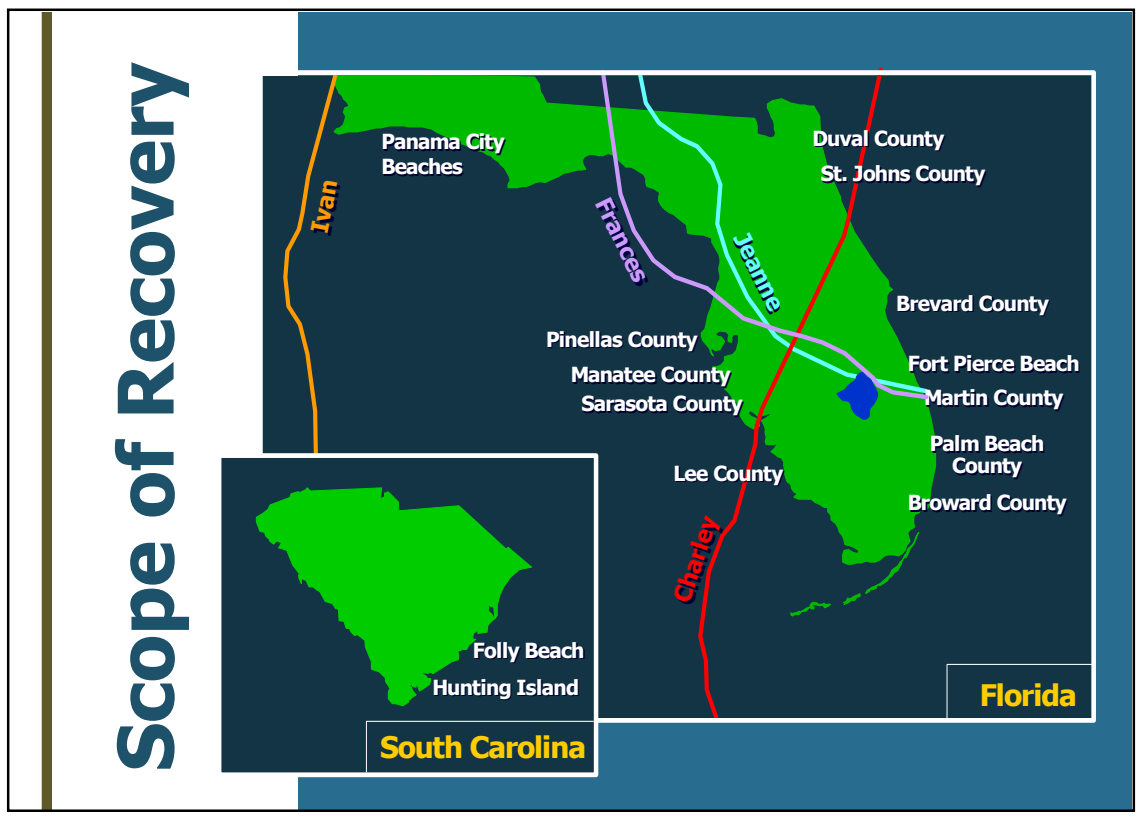

Figure 3: Location of the Federal SPP eligible for emergency restoration.

\subsection{Results of emergency response}

Of the 30 projects evaluated, 17 were found to meet the eligibility criteria set forth for emergency restoration. Those projects and their location with respect to the southeast US are shown in Figure 3. Project specific information is provided 
in Table 1, USACE 2005 [1]. This information includes the name of the project, its length, MHW shoreline recession and erosion losses resulting from the storm, the volume of material required to restore the project to its authorized design profile, the cost to restore the project, and the date restoration was completed.

Table 1: $\quad$ List of eligible Federal SPP and storm related information.

\begin{tabular}{|c|c|c|c|c|c|c|}
\hline $\begin{array}{c}\text { Federal Shore } \\
\text { Protection } \\
\text { Projects } \\
\end{array}$ & $\begin{array}{l}\text { Project } \\
\text { Length } \\
\text { (Miles) } \\
\end{array}$ & $\begin{array}{c}\text { Average } \\
\text { Storm } \\
\text { MHW } \\
\text { Recession } \\
\text { (Feet) } \\
\end{array}$ & $\begin{array}{l}\text { Storm } \\
\text { Losses } \\
\text { (Cubic } \\
\text { Yards) } \\
\end{array}$ & $\begin{array}{c}\text { Design } \\
\text { Profile } \\
\text { Volume } \\
\text { (Cubic } \\
\text { Yards) } \\
\end{array}$ & $\begin{array}{c}\text { Restoration } \\
\text { Costs }\end{array}$ & $\begin{array}{c}\text { Date } \\
\text { Emergency } \\
\text { Restoration } \\
\text { Completed } \\
\end{array}$ \\
\hline \multicolumn{7}{|l|}{ Florida } \\
\hline $\begin{array}{l}\text { Palm Beach- } \\
\text { Delray Beach }\end{array}$ & 2.5 & 52 & 428,500 & 428,500 & $\$ 4,825,600$ & 24-Apr-05 \\
\hline Martin County & 3.75 & 37.8 & 269,500 & 810,000 & $\$ 8,543,258$ & 28-Apr-05 \\
\hline $\begin{array}{l}\text { Brevard County- } \\
\text { N. Reach }\end{array}$ & 9.4 & 46 & 875,000 & 875,000 & $\$ 799,375$ & 15-May-05 \\
\hline $\begin{array}{l}\text { Brevard County- } \\
\text { S. Reach }\end{array}$ & 3.4 & 14.6 & 185,000 & 723,000 & $\$ 9,109,346$ & 15-May-05 \\
\hline Ft. Pierce Beach & 1.3 & 37.8 & 143,000 & 650,000 & $\$ 36,153,520$ & 6-Jun-05 \\
\hline Duval County & 5.7 & 81 & 420,180 & 665,000 & $\$ 7,317,889$ & 7-Aug-05 \\
\hline Sarasota County & 3.25 & 34 & 269,000 & $1,000,000$ & $\$ 13,302,795$ & 2-Sep-05 \\
\hline St. Johns County & 2.5 & 146 & 839,100 & $2,436,000$ & $\$ 16,103,697$ & 15-Dec-05 \\
\hline $\begin{array}{l}\text { Palm Beach- } \\
\text { Ocean Ridge }\end{array}$ & 1.4 & 17.8 & 168,000 & 585,000 & $\$ 3,716,999$ & 19-Dec-05 \\
\hline $\begin{array}{l}\text { Broward County } \\
\text { III }\end{array}$ & 6.6 & 5.5 & 196,000 & 196,000 & $\$ 2,994,200$ & 27-Jan-06 \\
\hline $\begin{array}{l}\text { Lee County- } \\
\text { Captiva Island }\end{array}$ & 4.6 & 11.3 & 157,100 & $1,305,000$ & $\$ 15,130,808$ & 3-Feb-06 \\
\hline $\begin{array}{l}\text { Pinellas County- } \\
\text { Sand Key }\end{array}$ & 9 & 34.4 & 251,000 & $1,200,000$ & $\$ 32,828,000$ & 1-Jun-06 \\
\hline Manatee County & 4.2 & 46.9 & 409,000 & 409,000 & $\$ 5,063,500$ & 1-Jun-06 \\
\hline $\begin{array}{l}\text { Panama City } \\
\text { Beaches }\end{array}$ & 17 & 22.4 & $2,412,000$ & $3,962,000$ & $\$ 30,298,238$ & 30-Sep-06 \\
\hline $\begin{array}{l}\text { Broward County } \\
\text { II }\end{array}$ & 1.3 & 13.7 & 293,700 & 293,700 & $\$ 3,784,800$ & 30-Sep-08 \\
\hline \multicolumn{7}{|l|}{ South Carolina } \\
\hline Hunting Island & 0.5 & 60 & 77,300 & 77,300 & $\$ 1,839,000$ & 19-May-05 \\
\hline Folly Beach & 5.45 & 26.7 & 510,240 & $2,338,000$ & $\$ 13,097,200$ & 19-Dec-05 \\
\hline TOTALS & 81.85 & & $7,903,620$ & $17,953,500$ & $\$ 204,908,225$ & \\
\hline
\end{tabular}

\section{Performance of protected versus unprotected beaches}

Storm impacts on Federal SPP resulted in an estimated loss of 8 million cubic yards of sand from 17 projects, as can be seen in Table 1. These projects prevented an estimated $\$ 800$ million in damages, Haubner et al. [5]. There was little or no damage to upland structures from erosion or direct wave impact at these project sites. The same cannot be said for unprotected or unnourished beaches. Storm-related sand volume losses on unnourished shorelines resulted in 
reduced protection to upland development, increased sea turtle nest destruction, and loss of tourism revenue. The storms caused major shoreline erosion, critical structural damage to coastal communities and impacted the beaches in a variety of locations. For instance, the Brevard County SPP provided substantial protection to the upland properties - there was no documented damage in those areas due to the storm surges, waves, or erosion from Hurricanes Frances and Jeanne, Clark [6]. In contrast, substantial damage outside of the project area was evident. In addition, the cumulative effects of both Frances and Jeanne on the unnourished shoreline north of the Ft. Pierce Beach SPP resulted in the most extreme erosion seen along the east coast of Florida in recent memory, Clark [6]. Along much of unnourished Estero Island in Lee County, which was identified as critically eroded prior to Hurricane Charley, as much as 200 feet of shoreline recession was experienced, Clark [6]. In comparison, the Captiva Island SPP, located just north of Estero Island, mitigated storm surge and wave damage. Had the beach restoration project not existed, it is highly probable that the primary evacuation route would have been destroyed or severely damaged.

\section{Summary and conclusions}

With four major hurricanes impacting the state, the tropical storm season of 2004 was the most active in Florida's history. The combined effects of the hurricanes were widespread. Each hurricane was unique in terms of its size, forward speed, storm surge, and wind strength; as a result, each was unique in terms of its impacts and devastation. Proving poised and capable of carrying out effective disaster relief missions, the USACE efficiently managed and executed a $\$ 800$ million recovery effort. Emergency relief was provided to hurricane victims by working with other agencies to re-roof homes, providing temporary power to critical infrastructure, ensuring victims had ice and potable water, and assisting them in finding temporary housing. In addition, to meeting the immediate needs of the victims, the USACE restored 82 miles of coastline by placing more sand than it had placed in the entire preceding decade, Haubner et al. [5]. As shown in Table 1, a total of 17 Federal SPP, 15 in Florida and two in South Carolina, were nourished with over 18 million cubic yards of sand. These accomplishments were critical to the success of the relief and restoration efforts in advance of the 2005 Atlantic tropical storm season. Unbeknownst to anyone at the time, the hurricane season of 2005 would eclipse any on record.

Although the hurricanes caused portions of the shoreline to retreat and threaten structures, the SPP significantly reduced the level of storm damage compared to that experienced by unprotected beaches. Major structures upland of Federal SPP suffered no damage from beach erosion-related undermining while structural and economic losses associated with significant shoreline recession and erosion were experienced in the areas unnourished. The performance of nourished beaches during the 2004 hurricane season proves that beach nourishment is vital to the protection of coastal infrastructure, beach environment and economic growth. 


\section{References}

[1] US Army Corps of Engineers (USACE) 2005, Project Information Reports for Duval County, St. Johns County, Brevard County, Ft. Pierce Beach, Martin County, Palm Beach County, Broward County, Lee County, Sarasota County, Manatee County, and Pinellas County, Jacksonville District, Jacksonville, Florida.

[2] Florida Department of Environmental Protection (FDEP) September 2004, Hurricane Frances and Hurricane Jeanne, Post-storm Beach Conditions and Coastal Impact Report with Recommendations for Recovery and Modifications of Beach Management Strategies, Division of Water Resource Management, Bureau of Beaches and Coastal Systems.

[3] Florida Department of Environmental Protection (FDEP) August 2004, Hurricane Charley, post-storm beach conditions and coastal impact report with recommendations for recovery and modifications of beach management strategies, Bureau of Beaches and Coastal Systems.

[4] Florida Department of Environmental Protection (FDEP) September 2004, Hurricane Ivan, Beach and Dune Erosion and Structural Damage Assessment and Post-Storm Recovery Plan for the Panhandle Coast of Florida, Division of Water Resource Management, Bureau of Beaches and Coastal Systems.

[5] Haubner, D. R., McMillen, R., Schmidt, D. V., Amundson, K., US Army Corps of Engineers Response to the Hurricanes of 2004, Shore and Beach Vol. 73, No. 2\&3.

[6] Clark, R., Impact of 2004 North Atlantic Hurricane Season on the Coast of Florida, Shore and Beach Vol. 73, No. 2\&3. 